\title{
Magma storage dynamics in off-rift volcanic systems in Western Iceland: insights from the Snafellsnes volcanic zone (SNVZ)
}

\author{
MAREN KAHL ${ }^{1}$, ENIKŐ BALI ${ }^{2}$, GUĐMUNDUR H. \\ GUĐFINNSSON $^{2}$, DAVID A NEAVE ${ }^{3}$, TERESA UBIDE ${ }^{4}$, \\ QUINTEN H. A. VAN DER MEER ${ }^{2}$ AND SIMON \\ MATTHEWS $^{2}$ \\ ${ }^{1}$ Heidelberg University \\ ${ }^{2}$ University of Iceland \\ ${ }^{3}$ The University of Manchester \\ ${ }^{4}$ The University of Queensland \\ Presenting Author: maren.kahl@geow.uni-heidelberg.de
}

Establishing the conditions and dynamics of pre-eruptive magma storage and transfer within transient transcrustal storage networks is a major focus of quantitative volcanic petrology. In Iceland, the behaviour, conditions and timescales of magma storage, mixing and transfer within on-rift magmatic plumbing systems are increasingly well constrained, but relatively little is known about magma storage and transfer in off-rift zones. Here, we present a combined geochemical and geothermobarometric study of magma storage and transfer recorded in the products of the postglacial Búðahraun $(\sim 5.0-8.0 \mathrm{ka})$ and Berserkjahraun $(\sim 4.0 \mathrm{ka})$ eruptions within the Snæfellsnes volcanic zone (SNVZ). The eruption products reveal diverse and compositionally heterogeneous macrocryst cargoes recording complex petrogenetic histories of crystal evolution and amalgamation from different parts of the sub-volcanic plumbing systems. Geothermobarometry indicates two compositionally and thermally heterogeneous magma storage regions located in the lower and upper-mid crust. Crystallisation pressure and depth estimates coincide with similar estimates from Vatnafell, a nearby small sub-glacial table mountain (tuya), indicating that the nature and conditions of magma storage within the central parts of the SNVZ have remained unchanged since the Upper Pleistocene. Trace element zoning of clinopyroxene macrocrysts indicates that mafic recharge into the upper-mid-crustal storage zone triggered the eruptions of Búðahraun and Berserkjahraun. Evidence for eruption triggering by mafic recharge and basaltic cannibalism involving the transfer and amalgamation of crystals with different histories sets both eruptions apart from other known eruptions in Iceland. We propose that the compositional and textural diversity preserved within the crystal cargoes is a direct consequence of the reduced heat flow beneath the SNVZ, which favours the formation of isolated melt pockets, in which the compositionally diverse macrocryst populations formed. Periodic flushes of primitive basaltic magma from depth promote widespread mixing with evolved melts, resulting in the assembly of crystals with diverse ancestries from different parts of the subvolcanic systems. Insights gained from the diverse macrocryst cargoes and comparison with recent off-rift volcanism are essential for the development of future monitoring efforts and hazard evaluation along the poorly instrumented Snæfellsnes 